\title{
Unique nest architecture in the North African osmiine bee Hoplitis (Hoplitis) mucida (Hymenoptera, Megachilidae)
}

\author{
Andreas Müller', Volker Mauss², Rainer Prosi ${ }^{3}$ \\ I ETH Zurich, Institute of Agricultural Sciences, Biocommunication and Entomology, Schmelzbergstrasse 9/ \\ LFO, 8092 Zurich, Switzerland 2 Staatliches Museum für Naturkunde, Abt. Entomologie, Rosenstein 1, \\ 70191 Stuttgart, Germany 3 Lerchenstrasse 81, 74564 Crailsheim, Germany
}

Corresponding author: Andreas Müller (andreas.mueller@usys.ethz.ch)

Academic editor: J. Neff | Received 11 August 2017 | Accepted 10 October 2017 | Published 30 October 2017
http://zoobank.org/BE259560-7551-47E6-88F7-B7A5E82BAAD9

Citation: Müller A, Mauss V, Prosi R (2017) Unique nest architecture in the North African osmiine bee Hoplitis (Hoplitis) mucida (Hymenoptera, Megachilidae). Journal of Hymenoptera Research 60: 99-109. https://doi.org/10.3897/ jhr.60.20218

\begin{abstract}
The osmiine bee species Hoplitis mucida is considered to consist of two subspecies with $H$. mucida mucida (Dours, 1873) ranging from northwestern Africa to Israel and Jordan and H. mucida stecki (Frey-Gessner, 1908) occurring in southwestern Europe and Sicily. The discovery of nests of $H$. mucida in Morocco and Tunisia revealed striking differences in the nesting biology of the two subspecies. In North Africa, females construct fully exposed, cake-like nests of mud on the flat surface of rocks and stones containing 8-12 vertically oriented brood cells, rendering these nests unique among osmiine bees regarding both nesting site and nest architecture. In contrast, in Europe females build their few-celled mud nests inside small rock cavities. This discrepancy in the nesting biology is paralleled by considerable morphological differences between the two subspecies suggestive of a long geographical isolation. Due to these biological and morphological differences, we propose to elevate the European subspecies H. mucida stecki to species rank.
\end{abstract}

\section{Keywords}

Apiformes, Echium, heat tolerance, Hoplitis adunca species group, labial glands

Copyright Andreas Müller et al. This is an open access article distributed under the terms of the Creative Commons Attribution License (CC BY 4.0), which permits unrestricted use, distribution, and reproduction in any medium, provided the original author and source are credited. 


\section{Introduction}

The osmiine bee species Hoplitis mucida (Dours, 1873) is a member of the large subgenus Hoplitis Klug, which comprises about 90 described and 50 undescribed species restricted to the Palaearctic region (Müller 2017). Within this subgenus, H. mucida belongs to the Hoplitis adunca species group representing the most basal member of that clade (Sedivy et al. 2013a). It is morphologically well characterized by its large size, lack of distinct hair bands along the tergal margins and two unique characters in the male sex, i.e. the hooked last antennal segment and the four-toothed tergum 6 (Amiet et al. 2010, Müller 2016). The distribution area of $H$. mucida encompasses southwestern Europe, Sicily, the Maghreb (Morocco, Algeria, Tunisia) and the Levant (Israel and Palestine, Jordan) (Müller 2017). Based on morphologically deviating specimens from Switzerland, Frey-Gessner (1908) established the subspecies H. mucida stecki (FreyGessner, 1908), which was later found by Warncke (1992) to be distributed throughout southwestern Europe. The division of $H$. mucida into a European and a non-European subspecies was followed by later authors (Ungricht et al. 2008, Müller 2017).

Hoplitis mucida is narrowly oligolectic, it exclusively collects pollen on flowers of Echium L. (Boraginaceae) throughout the entire species' range (Sedivy et al. 2013b). The discovery of a nest in southern Spain consisting of a single brood cell hidden in a small rock cavity and constructed from mud (Le Goff 2005) revealed that the nesting biology of $\mathrm{H}$. mucida closely corresponds to that of many other members of the Hoplitis adunca species group, which also build nests in depressions, fissures or holes of stones and rocks, and use mud as main nest building material (Sedivy et al. 2013a).

In spring 2017, two nests of Hoplitis mucida were found in southern Morocco, which strongly differed from the nest discovered in Spain with respect to both nesting site and nest architecture. These two Moroccan nests were very similar to a nest of $H$. mucida found in northern Tunisia in spring 2012 indicating striking differences in the nesting biology between North African and European populations. This discrepancy in nesting behaviour is paralleled by morphological differences between populations of North Africa and the Levant on the one hand and European populations on the other hand (Pérez 1902, Frey-Gessner 1908, Mavromoustakis 1947, Zanden 1990, Warncke 1992).

In the present contribution, we describe the peculiar North African nests of Hoplitis mucida, reevaluate the morphological differences between non-European and European populations and - based on both nesting biology and morphology - propose to elevate the European subspecies $H$. mucida stecki to species rank.

\section{Methods}

Two nests of Hoplitis mucida were found in southern Morocco near Tlata Uonass about $4 \mathrm{~km}$ east of Ait Baha $\left(30^{\circ} 03^{\prime} 42^{\prime \prime} \mathrm{N}\right.$; 9 $\left.9^{\circ} 06^{\prime} 55^{\prime \prime} \mathrm{W}\right)$ at an elevation of $610 \mathrm{~m}$ a.s.l. on 16 April 2017. One nest was already finalized, whereas the female of the second nest applied the last portions of mud onto its nest before she finally left the nesting 
site shortly after. As both nests adhered to large stones or rocks, which could not be transported back to the lab to let the bees emerge, the nests were opened with a knife to ascertain the number and arrangement of the brood cells. An additional nest of $H$. mucida was discovered in northern Tunisia near Sidi Mtir about $17 \mathrm{~km}$ southwest of El Kef (36 $\left.03^{\prime} 16^{\prime \prime} \mathrm{N} ; 8^{\circ} 36^{\prime} 26^{\prime \prime} \mathrm{E}\right)$ at an elevation of $510 \mathrm{~m}$ a.s.l. on 28 April 2012. This nest was initially attributed to an unknown species of Megachile (Chalicodoma) but later turned out to belong to $H$. mucida based on the bees that emerged in the lab.

To exclude the possibility that the discrepancy in the nesting behaviour between North African and European populations of Hoplitis mucida is simply due to a misidentification, the correct determination of the female that had constructed the nest discovered in southern Spain (Le Goff 2005) was confirmed by examining the voucher specimen kindly provided by G. Le Goff.

To find new and reevaluate already published morphological differences (Pérez 1902, Frey-Gessner 1908, Mavromoustakis 1947, Zanden 1990, Warncke 1992) between non-European and European populations of Hoplitis mucida, 21 females and 10 males of $H . m$. mucida (originating from Morocco, Tunisia, Israel and Jordan) and 16 females and 8 males of $H$. m. stecki (originating from Portugal, Spain, southern France, northern Italy and Sicily) were investigated under a stereomicroscope. Morphological terminology follows Michener (2007) with the following specifications: i) the distance between lateral ocellus and preoccipital ridge was measured in top view rather than in lateral view; ii) the diameter of the lateral ocellus was measured under inclusion of the ocellar border, which is of the same colour as the surrounding cuticle thereby differing from the light colour of the central part of the ocellus; iii) the numbering of the antennal segments starts from the scape, which is antennal segment 1 .

\section{Results}

\section{Nesting site and nest architecture}

The three nests of Hoplitis mucida found in Morocco and Tunisia had been constructed freely on horizontal to slightly sloping and almost flat surfaces of stones and rocks (Table 1, Figs 1-6). The stones serving as substrate for nests 1 and 3 were immovable as they were partly buried in the ground. All three nests were completely built from mud including small sand grains but without addition of larger pebbles. They were extremely hard and adhered strongly to the substrate making it impossible to remove them from the stony surface without damaging them.

The three nests were all of roundish to oval shape measuring $4.5-6.2 \mathrm{~cm}$ in maximal length, $4.0-5.1 \mathrm{~cm}$ in maximal width and $1.7-2.0 \mathrm{~cm}$ in maximal height (Table 1). The flat upper surface of the two Moroccan nests slightly projected beyond the concave sides (Figs 2, 5), whereas the Tunisian nest lacked a projecting rim and had convexe sides (Fig. 6).

The nests contained 8-12 brood cells, which had been built side by side (Table 1, Figs 3, 6). From nest 3, which contained 11 cells, four females and five males emerged 

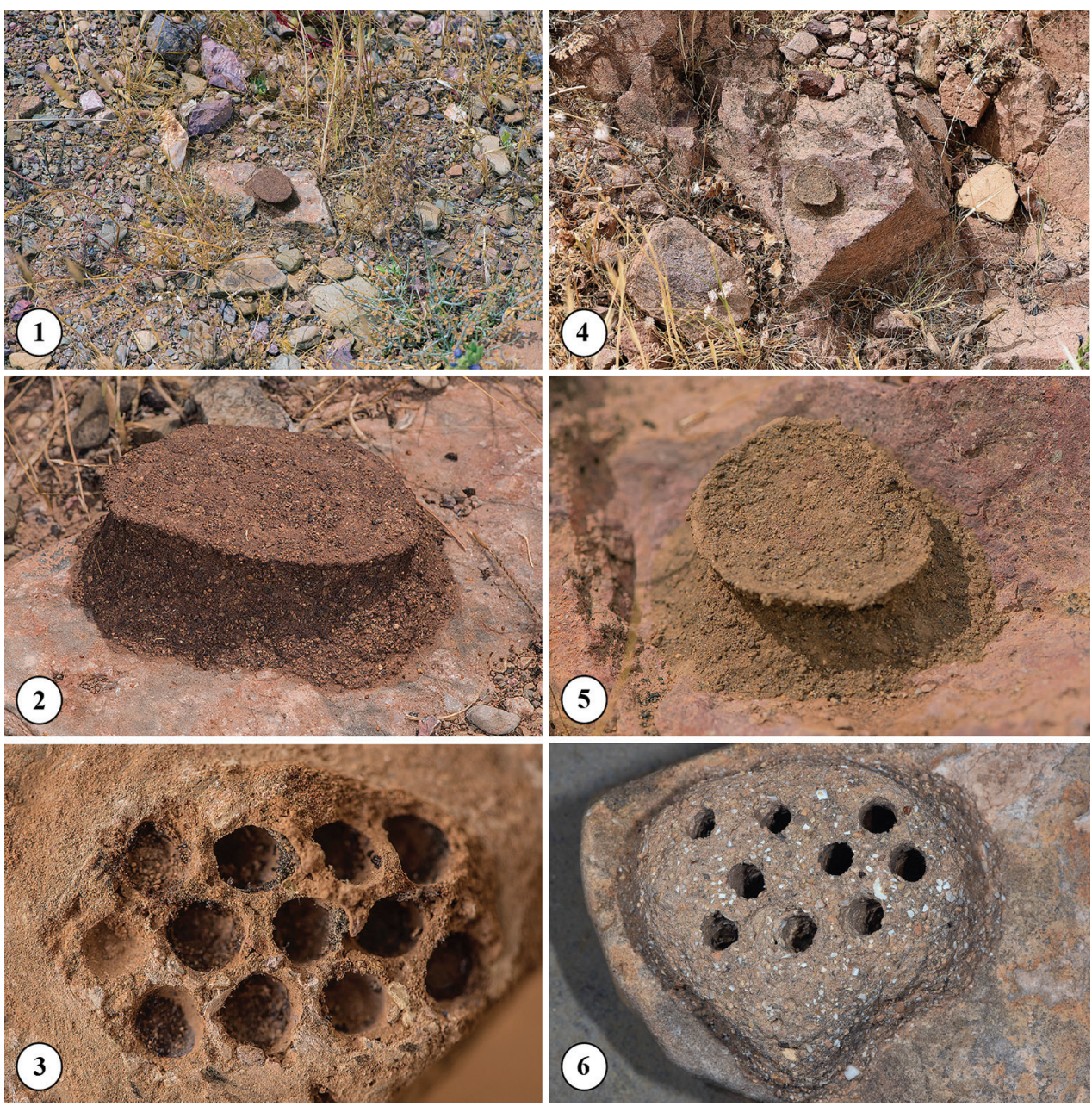

Figures I-6. Nests of Hoplitis mucida (see Table 1): I-2 Nest 1 near Ait Baha in southern Morocco glued to the flat surface of a middle-sized stone 3 Nest 1 opened shortly after its finalization with cell contents removed 4-5 Nest 2 near Ait Baha in southern Morocco glued to the flat surface of a rock $\mathbf{6}$ Nest 3 originating from near El Kef in northern Tunisia glued to the flat surface of a small stone and photographed after bee emergence.

(Fig. 6), whereas the bees in the remaining two cells had died during their development. As the careful examination of the contact zones between adjacent brood cells revealed double walls (Fig. 3), the wall of each new cell had been mortared directly onto the wall of the neigbouring cell. The longitudinal axes of the brood cells in all three nests were oriented almost perpendicular to the stony surface (Figs 3, 6), indicating that the first cell had been built freely upright without lateral support by the substrate. As the more central cells of nest 1 contained larvae that already had spun a cocoon whereas the outer cells still contained large amounts of pollen, the construction of the brood cells had proceeded from the inside to the outside. The examination of opened nests 
Table I. Characteristics of three nests of Hoplitis mucida (Dours 1873) discovered in North Africa.

\begin{tabular}{l|c|c|c}
\hline & $\begin{array}{c}\text { Nest 1 } \\
\text { (Figs 1-3) }\end{array}$ & $\begin{array}{c}\text { Nest 2 } \\
\text { (Figs 4-5) }\end{array}$ & $\begin{array}{c}\text { Nest 3 } \\
\text { (Fig. 6) }\end{array}$ \\
\hline Locality & $\begin{array}{c}\text { near Ait Baha in southern } \\
\text { Morocco }\end{array}$ & $\begin{array}{c}\text { near Ait Baha in southern } \\
\text { Morocco }\end{array}$ & $\begin{array}{c}\text { near El Kef in northern } \\
\text { Tunisia }\end{array}$ \\
\hline Nest substrate & $\begin{array}{c}\text { middle-sized stone } \\
(28 \mathrm{~cm} \times 18 \mathrm{~cm}) \text { partly } \\
\text { buried in the ground }\end{array}$ & rock & $\begin{array}{c}\text { small stone }(16 \mathrm{~cm} \times 7 \mathrm{~cm}) \\
\text { partly buried in the ground }\end{array}$ \\
\hline $\begin{array}{l}\text { Maximal length } \times \text { maximal } \\
\text { width of nest }\end{array}$ & $6.2 \mathrm{~cm} \times 5.1 \mathrm{~cm}$ & $4.5 \mathrm{~cm} \times 4 \mathrm{~cm}$ & $5.4 \mathrm{~cm} \times 4.8 \mathrm{~cm}$ \\
\hline Maximal height of nest & $2.0 \mathrm{~cm}$ & $1.9 \mathrm{~cm}$ & $1.7 \mathrm{~cm}$ \\
\hline Sides of nest & concave & 8 & convex \\
\hline Number of brood cells & 12 & 8 & 11 \\
\hline
\end{tabular}

revealed substantial amounts of mud added to both the top and the lateral sides of the nest (Fig. 3). Thus, the females had smoothed out irregularities and hollow spaces between the apical ends of the brood cells as well as between the walls of the outermost cells with mud, which resulted in a contiguous and uniform top and lateral layer giving the nest a cake-like form completely concealing the shape of the brood cells (Figs 2, 5). The question whether this extra addition of mud had started after all brood cells had been finalized or already earlier remains open. However, based on the observation that the female of nest 1 applied mud onto the flat upper nest surface before she finally left the nesting site, we hypothesize that the construction of the top layer is the last part of the nest building activity probably preceded by the building of the side layer.

\section{Morphology}

The examination of specimens of Hoplitis mucida collected throughout the species' distribution area revealed distinct morphological differences in both sexes between individuals from North Africa and the Levant on the one hand and individuals from southwestern Europe and Sicily on the other hand (Table 2, Figs 7-18), supporting the findings of earlier authors (see Introduction). In contrast, no clear morphological differences were found among individuals originating from Morocco, Tunisia, Israel and Jordan and among individuals collected in Portugal, France, northern Italy and Sicily, respectively.

\section{Discussion}

\section{Nesting site and nest architecture}

Among bees, exposed nests constructed from mud and glued to the surface of stones and rocks are known only from a few taxa of megachiline and osmiine bees. Freestanding mud nests occur in numerous Megachile species of the subgenus Chalicodoma 
Table 2. Biological and morphological differences between Hoplitis mucida (Dours, 1873) and H. stecki (Frey-Gessner, 1908).

\begin{tabular}{|c|c|c|}
\hline & Hoplitis mucida & Hoplitis stecki \\
\hline Distribution & $\begin{array}{l}\text { Maghreb (Morocco, Algeria, Tunisia) and } \\
\text { Levant (Israel and Palestine, Jordan) }\end{array}$ & $\begin{array}{c}\text { southwestern Europe (Iberian Peninsula, } \\
\text { southern France, northern Italy, southern Swit- } \\
\text { zerland) and Sicily }\end{array}$ \\
\hline $\begin{array}{l}\text { Nesting } \\
\text { biology }\end{array}$ & $\begin{array}{c}\begin{array}{c}\text { free-standing, cake-like nests constructed from } \\
\text { mud on horizontal and flat surfaces of stones } \\
\text { and rocks containing } 8-12 \text { brood cells }\end{array} \\
\end{array}$ & $\begin{array}{c}\text { hidden nests built in small cavities of rocks } \\
\text { containing one to possibly few brood cells } \\
\text { constructed from mud (Le Goff 2005) }\end{array}$ \\
\hline \multirow{8}{*}{$\begin{array}{l}\text { Male } \\
\text { characters }\end{array}$} & $\begin{array}{c}\text { antennal segments } 6-12 \text { slightly shorter } \\
\text { than wide (Fig. } 7 \text { ) }\end{array}$ & $\begin{array}{c}\text { antennal segments 6-12 slightly longer } \\
\text { than wide (Fig. 8) }\end{array}$ \\
\hline & $\begin{array}{c}\text { distance between lateral ocellus and preoccipital } \\
\text { ridge } 1.5-1.65 \times \text { as long as ocellar diameter }\end{array}$ & $\begin{array}{c}\text { distance between lateral ocellus and preoccipital } \\
\text { ridge } 1.8-2 \times \text { as long as ocellar diameter }\end{array}$ \\
\hline & $\begin{array}{c}\text { pilosity of tergal discs less strongly developed, } \\
\text { on apical half of discs } 3-5 \text { distinctly shorter } \\
\text { than on basal half }\end{array}$ & $\begin{array}{c}\text { pilosity of tergal discs more strongly developed, } \\
\text { on apical half of discs 3-5 about as long as on } \\
\text { basal half }\end{array}$ \\
\hline & $\begin{array}{c}\text { apical rectangular plate of tergum } 7 \text { almost as } \\
\text { long as wide (Fig. 9) }\end{array}$ & $\begin{array}{l}\text { apical rectangular plate of tergum } 7 \text { distinctly } \\
\text { wider than long (Fig. 10) }\end{array}$ \\
\hline & $\begin{array}{l}\text { transversal subapical swellings of sterna } 2-4 \\
\text { more strongly developed }\end{array}$ & $\begin{array}{c}\text { transversal subapical swellings of sterna 2-4 less } \\
\text { strongly developed }\end{array}$ \\
\hline & $\begin{array}{l}\text { lateral lobes of membraneous appendage of } \\
\text { sternum } 6 \text { narrower and less diverging, separa- } \\
\text { ted from each other by a shorter incision and } \\
\text { densely covered with yellowish-white pilosity } \\
\text { (Fig. 11) }\end{array}$ & $\begin{array}{c}\text { lateral lobes of membraneous appendage of } \\
\text { sternum } 6 \text { wider and more diverging, separated } \\
\text { from each other by a deeper incision and } \\
\text { densely covered with yellowish-brown pilosity } \\
\text { (Fig. 12) }\end{array}$ \\
\hline & $\begin{array}{l}\text { apex of gonostylus and outer margin of penis } \\
\text { valve with distinctly longer hairs (Fig. 13) }\end{array}$ & $\begin{array}{l}\text { apex of gonostylus and outer margin of penis } \\
\text { valve with distinctly shorter hairs (Fig. 14) }\end{array}$ \\
\hline & $\begin{array}{c}\text { penis valve more or less parallel-sided except for } \\
\text { its apicalmost part and apically more rounded } \\
\text { (Fig. 13) }\end{array}$ & $\begin{array}{l}\text { penis valve tapering towards its apex and apical- } \\
\text { ly more acute (Fig. 14) }\end{array}$ \\
\hline \multirow{2}{*}{$\begin{array}{l}\text { Female } \\
\text { characters }\end{array}$} & $\begin{array}{l}\text { distance between lateral ocellus and preoccipital } \\
\text { ridge 1.5-1.6x as long as ocellar diameter } \\
\text { (Fig. 15) }\end{array}$ & $\begin{array}{c}\text { distance between lateral ocellus and } \\
\text { preoccipital ridge 1.8-1.9x as long as ocellar } \\
\text { diameter (Fig. 16) }\end{array}$ \\
\hline & $\begin{array}{c}\text { pilosity of tergal discs shorter, on discs } 3-4 \text { less } \\
\text { than } 1.5 \times \text { as long as maximal width of antennal } \\
\text { flagellum (Fig. 17) }\end{array}$ & $\begin{array}{c}\text { pilosity of tergal discs longer, on discs } 3-4 \\
\text { about } 2 \times \text { as long as maximal width of antennal } \\
\text { flagellum (Fig. 18) }\end{array}$ \\
\hline
\end{tabular}

(Praz 2017, and references therein) and in several Hoplitis species of the Hoplitis adunca species group (Sedivy et al. 2013a, and references therein). To the present knowledge, these species all prefer strongly inclined to vertical areas of stones and rocks for nesting, they usually build their nests in depressions or irregularities of the stony surface and the longitudinal axes of their brood cells are more or less parallel to the underground with the cells being often constructed in lateral contact to the substrate. In contrast, North African females of Hoplitis mucida select horizontal to slightly inclined areas for nesting, they build their nests on flat portions of the stony surface and the longitudinal axes of their brood cells are perpendicular to the underground with the cells being constructed upright without lateral contact to the substrate. These differences make the cake-like nests of North African populations of $H$. mucida unique among both megachilid bees and members of the Hoplitis adunca species group. 


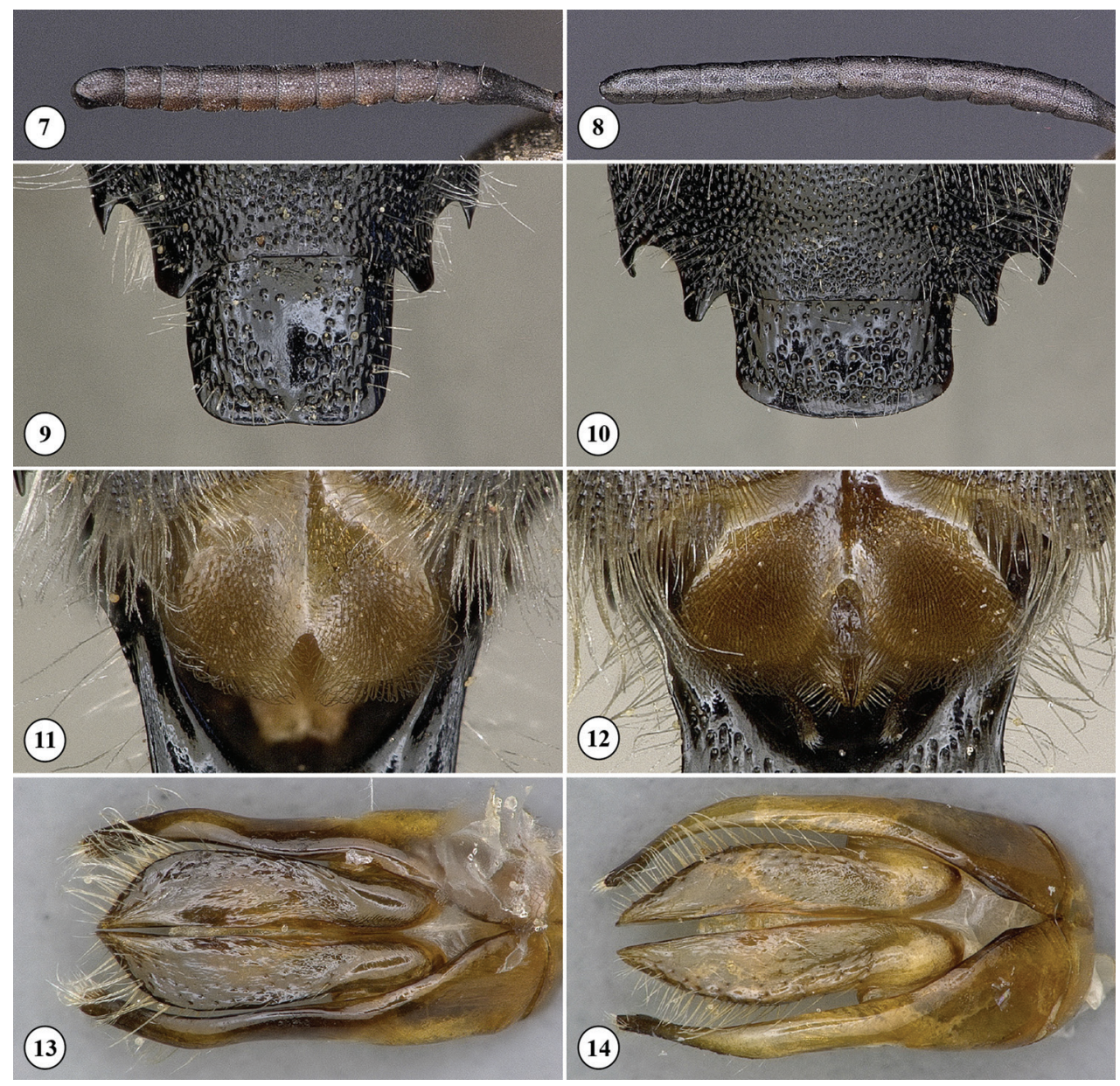

Figures 7-I4. Morphological differences in the male sex between Hoplitis mucida (left) and H. stecki (right) (see Table 2): 7-8 Antenna 9-10 Tergum 7 II-I 2 Membraneous appendage of sternum 6 |3-|4 Genitalia.

The nests of Hoplitis mucida were found to be extremely hard and it proved to be impossible to perforate their walls even with a strong knife. They are thus similary hard as the exposed mud nests of Megachile (Chalicodoma) species. The hardness of Megachile (Chalicodoma) nests is most probably due to the mixing of mud with secretions of the labial glands, which harden the mud and render the nests hydrophobic protecting them against the erosive effects of rain (Kronenberg and Hefetz 1984). It seems probable that the females of $H$. mucida also add glandular secretions to the collected mud to make the nests hard and weatherproof, suggesting the convergent evolution of a mud binding agent in these two only distantly related bee taxa. In fact, females of Hoplitis anthocopoides, a species that is closely related to $H$. mucida and also constructs free-standing mud nests, were observed to mix a fluid probably originating from the enlarged salivary glands with mud as the latter was collected on the ground (Eickwort 1973, 1975). 

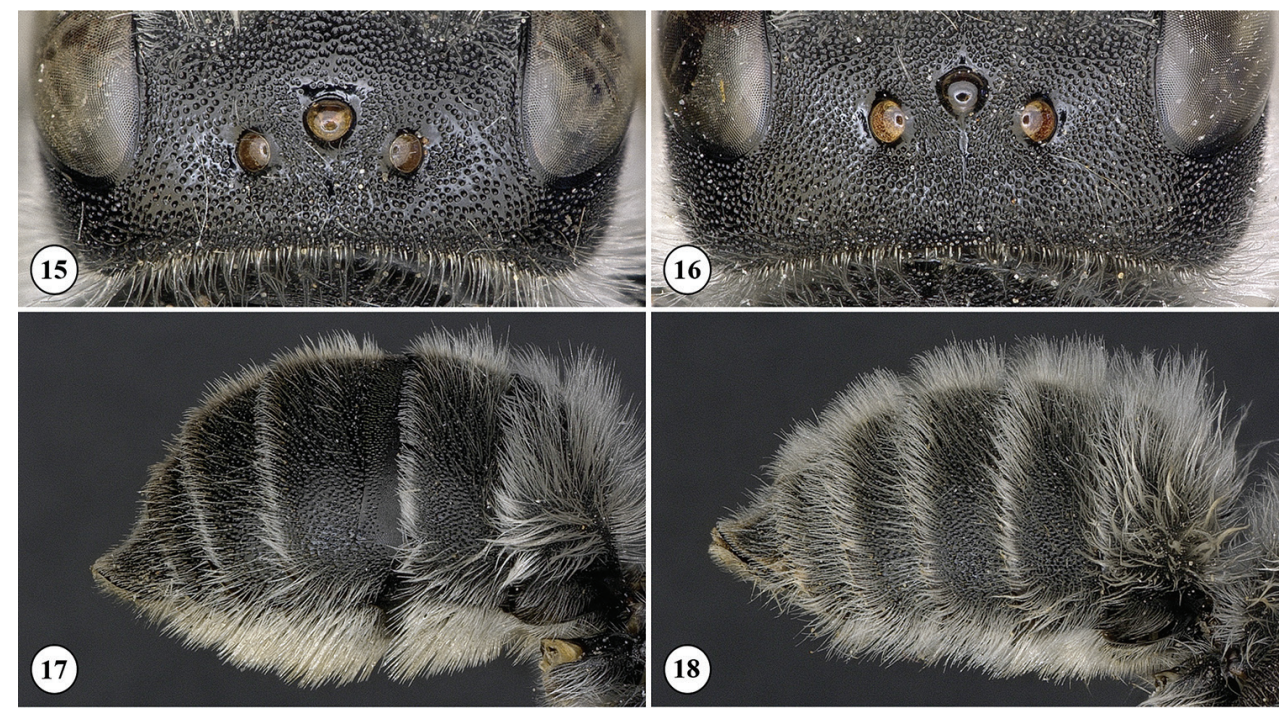

Figures I5-18. Morphological differences in the female sex between Hoplitis mucida (left) and H. stecki (right) (see Table 2): 15-16 Vertex I7-18 Pilosity of tergal discs.

The two nesting sites of Hoplitis mucida in southern Morocco and northern Tunisia are exposed to average maximum daily air temperatures during July and August of more than $30^{\circ} \mathrm{C}$ and $40^{\circ} \mathrm{C}$, respectively (https://de.climate-data.org), resulting in ground temperatures that may regularly reach far beyond $50^{\circ} \mathrm{C}$ during the day (Kerr et al. 1984). Thus, the larvae of $H$. mucida must have an amazing ability to withstand extreme temperatures given the fully sun-exposed position of the nests, the stony nest substrate and - at least in the two moroccan nests - the nonreflective dark colour of the nest building material. As all nests were found to have been finished mid to end April coincident with the end of the flowering period of Echium, the species' exclusive host plant, all larvae likely entered the prepupal stage till end of May latest before the environmental temperatures reached close-to-lethal levels. Thus, the ability to resist such extreme summer temperatures pertains to the diapausing prepupae of $H$. mucida.

Some members of the Hoplitis adunca species group known to build exposed mud nests at the surface of rocks and stones, such as Hoplitis anthocopoides, H. benoisti, $H$. loti or $H$. ravouxi, occasionally also nest in small holes and fissures, where their brood cells are more or less hidden (Sedivy et al. 2013a, and references therein). Obviously, these species have the flexibility to colonize rock cavities of variable shape and size, ranging from small holes often containing only one or two hidden brood cells to surface depressions or irregularities serving as substrate for free-standing nests with numerous cells. Given the highly elaborated and unique architecture of Moroccan and Tunisian nests of Hoplitis mucida, we consider it highly improbable that North African populations of $H$. mucida use small holes or fissures in rocks and stones as 
alternative nesting sites as the species mentioned above. Similarly, it appears highly unlikely that European $H$. mucida also build fully exposed, cake-like nests like their North African relatives since such conspicuous nests would certainly have been found in the well explored southwestern European region, where studies on the nesting biology of bees have a long tradition, particularly in France (e.g. Fabre 1879-1907, Ferton 1923). Instead, we strongly assume that the nesting biology of North African and European populations of $H$. mucida strongly differ with respect to both nesting site and nest architecture.

\section{Morphology}

The morphological analysis revealed a distinct morphological gap between non-European and European populations of Hoplitis mucida, but morphological uniformity among specimens distributed in the Maghreb and the Levant. This finding indicates that North African and southwestern European populations were geographically and genetically isolated for a long time and suggests that the separation of the populations of the Maghreb from those of the Levant is a rather recent event, possibly taking place at the end of the greening period of the Sahara about 6000 years before present (Claussen and Gayler 1997). Based on the lack of clear morphological differences between North African and Levantinian populations and their probably recent geographical separation, we expect the still unknown nesting biology of the latter to closely correspond to that described in the present contribution.

\section{Conclusion}

European populations of Hoplitis mucida substantially differ from North African populations in nesting site, nest architecture and morphology. These differences justify the recognition of the European populations as a biological species of its own. Thus, we propose to elevate the European subspecies $H$. mucida stecki to species rank, i.e. H. stecki (Frey-Gessner, 1908), stat. n.

\section{Acknowledgments}

C. Praz and C. Sedivy participated in an excursion to Tunisia in 2012. C. Praz bred the nest of $H$. mucida discovered in Tunisia in the lab. G. Le Goff provided the voucher female of the nest he found in Spain. H. Baur (Naturhistorisches Museum Bern) provided access to a digital imaging system for taking photomicrographs. Comments by V. Gonzalez, C. Praz, C. Rasmussen and J. Neff substantially improved the manuscript. 


\section{References}

Amiet F, Herrmann M, Müller A, Neumeyer R (2004) Apidae 4: Anthidium, Chelostoma, Coelioxys, Dioxys, Heriades, Lithurgus, Megachile, Osmia, Stelis. Fauna Helvetica 9: 1-273.

Claussen M, Gayler V (1997) The greening of the Sahara during the mid-Holocene: results of an interactive athmosphere-biome model. Global Ecology and Biogeography Letters 6: 369-377. https://doi.org/10.2307/2997337

Dours L (1873) Hyménoptères du bassin méditerranéen. Revue et Magasin de Zoologie Pure et Appliqué, ser. 3, 1: 274-325.

Eickwort GC (1973) Biology of the European mason bee, Hoplitis anthocopoides (Hymenoptera: Megachilidae), in New York State. Search Agriculture 3: 1-31.

Eickwort GC (1975) Nest-building behavior of the mason bee Hoplitis anthocopoides. Zeitschrift für Tierpsychologie 37: 237-254. https://doi.org/10.1111/j.1439-0310.1975.tb00879.x

Fabre J-H (1879-1907) Souvenirs entomologiques, Vol. 1-10. Delagrave, Paris.

Ferton C (1923) La vie des abeilles et des guêpes. Chiron, Paris, 1-376.

Frey-Gessner E (1908) Osmia mucida Dours (Hymen.). Mitteilungen der Schweizerischen Entomologischen Gesellschaft 11: 280-283.

Kerr A, Smith BJ, Whalley WB, McGreevy JP (1984) Rock temperatures from southeast Morocco and their significance for experimental rock-weathering studies. Geology 12: 306-309. https://doi.org/10.1130/0091-7613(1984)12<306:RTFSMA>2.0.CO;2

Kronenberg S, Hefetz A (1984) Role of labial glands in nesting behaviour of Chalicodoma sicula (Hymenoptera; Megachilidae). Physiological Entomology 9: 175-179. https://doi. org/10.1111/j.1365-3032.1984.tb00696.x

Le Goff G (2005) Seconde note sur des Hoplitis nidifiant dans des cavités rocheuses en Espagne: Hoplitis mucidoides v. der Zanden et $H$. marchali Pérez. Leur nidification et leurs parasites. Lambillionea 105: 513-516.

Mavromoustakis GA (1947) On some Megachilidae (Hym., Apoidea) from Spain and Morocco. Eos 23: 357-367.

Michener CD (2007) The bees of the world, second edition. Johns Hopkins University Press, Baltimore and London, 953 pp.

Müller A (2016) Hoplitis (Hoplitis) galichicae spec. nov., a new osmiine bee species from Macedonia with key to the European representatives of the Hoplitis adunca species group (Megachilidae, Osmiini). Zootaxa 4111: 167-176. https://doi.org/10.11646/zootaxa.4111.2.5

Müller A (2017) Palaearctic Osmiine Bees, ETH Zürich. http://blogs.ethz.ch/osmiini [accessed 1.6.2017]

Pérez J (1902) Espèces nouvelles de mellifères paléarctiques. Procès-verbaux de la Société Linnéenne de Bordeaux 57: 57-68.

Praz CJ (2017) Subgeneric classification and biology of the leafcutter and dauber bees (genus Megachile Latreille) of the western Palearctic (Hymenoptera, Apoidea, Megachilidae). Journal of Hymenoptera Research 55: 1-54. https://doi.org/10.3897/jhr.55.11255

Sedivy C, Dorn S, Müller A (2013a) Evolution of nesting behaviour and cleptoparasitism in a selected group of osmiine bees (Megachilidae). Biological Journal of the Linnean Society 108: 349-360. https://doi.org/10.1111/j.1095-8312.2012.02024.x 
Sedivy C, Dorn S, Widmer A, Müller A (2013b) Host range evolution in a selected group of solitary bees: the Boraginaceae-Fabaceae paradox. Biological Journal of the Linnean Society 108: 35-54. https://doi.org/10.1111/j.1095-8312.2012.02013.x

Ungricht S, Müller A, Dorn S (2008) A taxonomic catalogue of the Palaearctic bees of the tribe Osmiini (Hymenoptera: Apoidea: Megachilidae). Zootaxa 1865: 1-253.

Warncke K (1992) Die westmediterranen Arten der Bienen Osmia subg. Hoplitis Klug, 1807. Linzer Biologische Beiträge 24: 103-121.

Zanden G van der (1990) Nomenklatorische Änderungen für einige paläarktische Arten der Familie Megachilidae (Insecta, Hymenoptera, Apoidea). Reichenbachia 28: 51-54. 